\title{
BUSINESS CYCLES
}





\section{BUSINESS CYCLES}

D U R A T I O N S, D Y N A M I C S,

A N D F O R E C A S T I N G

Francis X. Diebold and Glenn D. Rudebusch 


\section{Copyright (c) 1999 by Princeton University Press}

Published by Princeton University Press, 41 William Street, Princeton, New Jersey 08540

In the United Kingdom: Princeton University Press, Chichester, West Sussex

\section{All Rights Reserved}

\section{Library of Congress Cataloging-in-Publication Data}

Diebold, Francis X., 1959-

Business cycles: durations, dynamics, and forecasting / Francis X. Diebold and Glenn D. Rudebusch.

$$
\text { p. } \mathrm{cm} \text {. }
$$

Includes bibliographical references and index.

ISBN 0-691-01218-0 (alk. paper)

1. Business cycles-Statistical methods.

2. Business forecasting-Statistical methods.

I. Rudebusch, Glenn D., 1959- . II. Title.

HB3711.D54 1999

$338.5^{\prime} 42^{\prime} 0151-\mathrm{dc} 21$

This book has been composed in Times Roman.

The paper used in this publication meets the minimum requirements of ANSI/NISO Z39.48-1992 (R1997) (Permanence of Paper)

http://pup.princeton.edu

Printed in the United States of America

$\begin{array}{llllllllll}10 & 9 & 8 & 7 & 6 & 5 & 4 & 3 & 2 & 1\end{array}$ 
To

Susan, Hannah, and Frankie

and

Pat, Katherine, and Jane 
